\title{
Brief Analysis on the Present Situation and Future Development of Piano Education in China
}

\author{
Fan Yang*, Yu Shi \\ Shihezi University School of Art and Literature, Shihezi 832000, XinJiang, China. \\ E-mail: 446817030@qq.com
}

Fund Project: One of the research results of Xinjiang project of Ministry of education Youth Fund for Humanities and social sciences research on "The Influence and Enlightenment of Russian Piano School on Chinese Piano Art" (No.: 18xjjc760001)

\begin{abstract}
Piano originated in Europe. It is a keyboard instrument invented by Italian Bartolomeo Cristofori in 1709, known as the king of musical instruments. It is often used in solo, accompaniment, ensemble and other performances. The piano came into China at the end of the 19th century and the beginning of the 20th century. At first, the appreciation and acceptance of the piano by Chinese people was not high. Later, foreign missionaries often used the piano in the church. As time went by, people's acceptance of piano increased day by day. After the founding of new China, China's pianists won many awards in international piano competitions. After the reform and opening up, China's economy has developed rapidly, and it has also absorbed the culture from all over the world. More and more Chinese people begin to appreciate piano music and learn to play. Piano education has also entered the public's vision. In higher education, many art colleges and universities have set up piano learning related courses. Piano is no longer a rare thing hundreds of years ago, but gradually integrated into Chinese culture. At present, China's piano education has been orderly popularized, occupying a place in art education, but at the same time there are also some aspects worth thinking about the piano education in the cultivation of aesthetic and artistic accomplishment. From the current situation and development of China's piano education this paper gives the corresponding countermeasures.
\end{abstract}

Keywords: Chinese piano; piano education; piano art; education status

In 1915, musician Zhao Yuanren published "Peaceful March", the first piano music in China, which also marks the budding of Chinese piano music. After the reform and opening up, Liu Dunnan's Piano Concerto "Mountain Forest" marks the innovation and development of China's piano music. After nearly a century of development and exploration, China's piano education system has gradually formed and Li Yundi, Chen Sa and other outstanding young pianists have risen one after another. With the unremitting efforts of piano educators, China's piano education has made brilliant achievements.

\section{Summary of the current situation of piano education in China}

With the vigorous development of the national economy, the people's material conditions and spiritual needs are gradually improved. Piano is not a rare thing for ordinary families. Therefore, in order to make their children have certain achievements in music, many ordinary families have bought a piano and enrolled in a piano training class. From here on, piano education has gradually been mixed with utilitarianism and more than one reason caused this situation.

\subsection{The starting point of development is low}

We all know that piano originated in Europe and developed in the West. From the level of economic development,

Copyright (C) 2020 Fan Yang et al

doi: 10.18282/le.v9i6.1305

This is an open-access article distributed under the terms of the Creative Commons Attribution Non-Commercial License

(http://creativecommons.org/licenses/by-nc/4.0/), which permits unrestricted non-commercial use, distribution, and reproduction in any medium, provided the original work is properly cited. 
China's development level is far behind than that of the West. The economic foundation determines the superstructure. In terms of economy, China has fallen behind a lot, so there are also some deficiencies in cultural development. The investment in music education and the construction of music colleges and universities in western developed countries have a long history. Although China has a history of 5000 years, there has been rhythm since ancient times, due to the times of difficulties at home and abroad in the development process; the details of music have not been handed down for a long time. Compared with the west, the development of music education in China is not long. What's more, piano is an art that undertakes the western culture and has its own characteristics. Due to historical, cultural, economic and other reasons, the starting point of piano education in China is relatively low. If Western culture wants to integrate into Chinese culture, its difficulty can be imagined. Therefore, in the short time with low development stage, piano education in China needs to continuous exploration.

\subsection{The utility of learning piano is obvious}

Foreign piano education pays more attention to basic skills, especially the training on fingers, and advocates laying a good foundation for professional promotion. Its education form is relatively rich, so that students' personality and creative ability will be reflected. Because the piano itself is derived from the western culture and history, the teaching materials and repertoire as well as the related rhythm style are more in line with its teaching, so it is easier for domestic students to access the appropriate works, which is very difficult to achieve in our country. Combined with the elements of history, economy and politics, we can see that the concept of piano education in foreign countries is mainly regarded as a form of quality education, which can cultivate students' sentiment and improve their quality, so as to take the initiative to learn and maintain their unique musical quality for a long time. In China, combining the development of national musical instruments if it is not because of the more utilitarian, why don't parents choose the national musical instruments with rich cultural heritage for their children's learning and education? The reason is still that the purpose and form of Chinese piano learning is greater than the content, the test grade is greater than the cultivation of sentiment, and the students' skills are greater than the students' emotional cognition. In this case, parents only care whether piano education is helpful for children's further education, which in turn limits students' love for piano.

\subsection{There are few piano works in China}

A few years ago, after a Beethoven themed piano solo concert, Li Yundi was asked by a reporter why he did not choose Chinese repertoire as the performance theme. His answer is very realistic: there are very few works for pianists to perform. Most of the well-known songs in the world are from the adaptation of classic songs, such as "Butterfly Lovers" and so on, few original piano music. Although China has a long history and cultural heritage, at this stage, the importance of Chinese piano works has not been reflected in piano education and piano education have not been organically combined with national music. We should absorb the advanced western culture while also pay attention to our own national characteristics. With great number of Chinese piano works, students can have a deeper understanding of China's cultural heritage in piano education and national cultural awareness will also be improved, in this way our music culture will be more likely to be inherited and developed.

\subsection{Lack of piano teachers}

Mr. Deng Xiaoping once said that "education should start with the baby". As a developing country, China should pay special attention to education, and teachers are the most indispensable part of education. At present, the rapid development of piano education in China, with the number of piano children is increasing year by year, the shortage of teachers is serious, which also makes a group of so-called music teachers who are not professional enough to fish in troubled waters and destroy the education ecology. A qualified piano teacher needs many years of training. After graduation from a music college, he should be engaged in piano education and have a sense of responsibility for piano education. China's piano education is mainly divided into three important periods, namely, the enlightenment stage, the intermediate stage and the advanced stage. In each stage, the psychological state, learning ability and expression ability of students are different and the piano learning content also changes with the growth of age. In addition, after entering middle school, they need to take into account their studies, therefore, if the ability and sense of responsibility of teacher are insufficient, the students' learning effect will not be satisfactory. 


\section{Thinking on the future development of piano education in China}

\subsection{Strengthen the exchange of piano education}

Piano education has been introduced into China for more than a hundred years, which is the product of economic development and one of the means of quality education. With the rapid development of economic globalization and informatization, there are more and more exchanges between China and the world, including but not limited to culture and economy. Therefore, in the development process of Chinese piano education, we can strengthen the exchange with domestic and foreign piano education industry and hold cultural exchange meetings to learn from others' advanced methods, so as to promote the development of Chinese piano education.

\subsection{Promoting national art education}

Nationalization, in short, refers to the artist's creative way of showing and sublimating the art form and thinking mode of the nation, and describing the national thought, so that the literary and artistic works look more national style. The development of our country is diversified. Thus, we also need to improve the status of national culture in the world culture while attaching importance to national culture. If we can integrate the western piano performance with national creation, we can also form a precious art system, so as to make Chinese piano music go to the world. Let the piano from Europe play Chinese piano music with national cohesion, so as to promote the development of Chinese piano education and form our own national art aesthetics.

\subsection{Make good use of Internet intelligent technology}

With the continuous development of information technology, intelligent piano has also appeared. Piano education through internet intelligent technology can not only alleviate the plight of weak teachers, but also provide more efficient guidance to students. In addition to the functions of traditional piano, intelligent piano can also supervise and correct the students who practice playing through software. In this state, the pressure of piano teachers has been relieved, and the data-based education has reduced the burden of teachers, also a sense of company is achieved by students in the whole process. After the piano playing, the computer can intuitively see their own playing mistakes, so as to carry out targeted training. This whole intelligent education process can provide practical guidance for every student, and the quality of education will be improved.

\section{Conclusion}

Learning piano plays an important role in the cultivation and promotion of music literacy as well as music appreciation ability. Compared with the piano education in the west, although there are many deficiencies in China's piano education, we all know that education is not achieved overnight, and the teaching methods are not mechanically copied. Chinese piano education needs to explore via time and technology to form a suitable path. In particular, we should combine the national characteristics to form a piano education mode with Chinese characteristics, so as to effectively improve the national culture in the future.

\section{References}

1. Zhou Weimin. The History and Development of Piano Education in China. Chinese Music, 2010, 000(002):144-150.

2. Li Pingting. The Brief Analysis on the Present Situation and Future Development of Piano Education in China. Knowledge Base,2019, 000(014):P.29-29.

3. Chang Liwen. Overall Analysis and Thinking on the Development of Piano Education in China. Art Education, 2013, 000(004):73-73. 